\title{
"Community Dignity Takings": Dehumanization and Infantilization of Communities Resulting from the War on Drugs
}

\author{
Jamila Jefferson-Jones*
}

\section{INTRODUCTION}

The nearly half-century of the War on Drugs ${ }^{1}$ and the so-called "tough-on-crime" 2 policies that it spawned have gravely affected, not only the individuals who were convicted of offenses under this regime, but also their families and communities. ${ }^{3}$ A Pew Center study revealed that a number of tough-on-crime measures added to both the length of average prison stays and the number of incarcerated individuals. ${ }^{4}$ Often, these individuals come from and return to communities that have been ravaged

* Visiting Associate Professor of Law, University of Kansas (Spring 2018); Associate Professor of Law, University of Missouri-Kansas City.

1. The War on Drugs is a comprehensive policy aimed at the reduction of the illegal drug trade. See generally ALEXANDER CockBURn \& JeFFREY St. ClaiR, WhiteOUT: THE CIA, DRUGS AND THE PRESS (1998) (chronicling the history of the War on Drugs). It consists of the prohibition of drugs, the provision of military aid to and intervention in drug-producing countries, and the adoption of stringent enforcement policies. Id. President Ronald Regan officially declared the War on Drugs in 1982. Michelle Alexander, The New Jim Crow: Mass InCArceration in the Age of COLORBLINDNESS 5 (1st ed. 2010). Other scholars, however, claim earlier origins: For instance, Gerald López and John Acevedo note that this shift actually began in the 1970s. John Felipe Acevedo, Restoring Community Dignity Following Police Misconduct, 59 How. L. J. 621, 630 (2016) [hereinafter Acevedo, Restoring Community Dignity]; Gerald P. López, How Mainstream Reformers Design Ambitious Reentry Programs Doomed to Fail and Destined to Reinforce Targeted Mass Incarceration and Social Control, 11 HASTINGS RACE \& POVERTY L.J. 1, 4-5 (2014).

2. In many cases, prison populations soared as a result both of "sustained crackdown[s] on drug and quality of life crimes." The Pew Ctr. On The States, Time Served: The High Cost, Low Return of Longer Prison Terms 23 (2012) [hereinafter Pew Center, Time Served] (emphasis added), http://bridgemi.com/wp-content/uploads/2012/06/PSPP_Time-ServedReport_embargoed_June_6_2012.pdf.

3. See generally TODD R. ClEAR, IMPRISONING COMMUNITIES: HOW MASS INCARCERATION MAKES DISADVANTAGED NEIGHBORHOODS WORSE (2007) (examining the effect of the War on Drugs and mass incarceration on minority communities).

4. For instance, the Violent Crime Control and Law Enforcement Act of 1994 provided to states federal Violent-Offender Incarceration and Truth-In-Sentencing grants, provided that those classified as "violent offenders" served eighty-five percent of their original sentences. PEW CENTER, TIME SERVED, supra note 2, at 24. This prompted some states to accelerate prison expansion in order to comply. Id. "Moreover, many states have habitual offender laws with sentence enhancements that ... greatly boost[ed] time served in prison." Id. 
by the ongoing loss of their members to the War on Drugs. ${ }^{5}$ This war has produced casualties that are borne by the whole of the community, regardless of individual community members' criminal histories. These casualties include the loss of economic, political, and social capital caused by the removal of a disproportionate number of healthy, young adults at the height of their potential productivity. ${ }^{6}$ Moreover, when individuals do return home, they bring with them the wounds of this war in the form of the stigma of ex-offender status and the resulting collateral consequences of conviction. ${ }^{7}$

Commentators have noted that, "[t]he lasting consequences of a criminal conviction can be 'life-restricting . . . varied, and often bewildering. [Moreover], they can impact the most fundamental necessities of life-like a job, a place to live, and education." "8 Much has been written about the effects of these collateral consequences on both individuals with ex-offender status and on the communities from which they come and to which they return. ${ }^{9}$ In my earlier work, I noted that:

Most current discussions of collateral consequences of criminal conviction, reentry barriers and discrimination against those with criminal records center on one of two notions: (1) the fairness (or the

5. See generally, Robert J. Sampson \& Charles Loeffler, Punishment's Place: The Local Concentration of Mass Incarceration, 139 DAEDALus 20 (2010), https://www.ncbi.nlm.nih.gov/pmc/articles/PMC3043762/; Jeremy Travis, But They All Come Back: Rethinking Prisoner Reentry, SENTENCING \& CORRECTIONS: ISSUES FOR THE 21st CENTURY, May 2000 at 1 [hereinafter Travis, Rethinking Prisoner Reentry], https://www.ncjrs.gov/ pdffiles1/nij/181413.pdf.

6. Part II of this Article discusses the incarceration rates of young Americans.

7. "The 'collateral consequences' of criminal convictions are those that, rather than having been imposed upon the convicted individual by a sentencing judge, 'take effect outside of the traditional sentencing framework ... by operation of law [and are, therefore] not considered part of the practice or jurisprudence of sentencing." Jamila Jefferson-Jones, A Good Name: Applying Regulatory Takings Analysis to Reputational Damage Caused by Criminal History, 116 W. VA. L. REV. 497, 502 (2013) [hereinafter Jefferson-Jones, A Good Name] (quoting Jeremy Travis, Invisible Punishment: An Instrument of Social Exclusion, in Invisible Punishment: THE Collateral CONSEQUENCES OF MASS IMPRISONMENT 15, 16 (Marc Mauer \& Meda Chesney-Lind eds., 2002)).

8. Jamila Jefferson-Jones, Extending "Dignity Takings": Re-Conceptualizing the Damage Caused by Criminal History and Ex-Offender Status, 62 ST. LouIS L. J. 863, 864 (2018) [hereinafter Jefferson-Jones, Extending Dignity Takings] (quoting RAm SubRAMANian, REBECKa MoORE \& Sophia Gebreselassie, Vera Inst. of Justice, Relief in Sight? States Rethink the Collateral Consequences of Criminal Conviction, 2009-2014 2 (Dec. 2014), https://storage.googleapis.com/vera-web-assets/downloads/Publications/relief-in-sight-statesrethink-the-collateral-consequences-of-criminal-conviction-2009-2014/legacy_downloads/statesrethink-collateral-consequences-report-v4.pdf [https://perma.cc/VA77-H2JY]).

9. See generally CLEAR, supra note 3; Michael Pinard \& Anthony C. Thompson, Offender Reentry and the Collateral Consequences of Criminal Convictions: An Introduction, 30 N.Y.U. REV. L. \& SOC. CHANGE 585 (2006) (chronicling housing, employment, and voting rights barriers faced by ex-offenders). 
lack thereof) of continued, unforeseen, or disproportional punishment; or (2) the role of legislatures and the executive (in the guise of administrative agencies) usurping the sentencing function of the judiciary through the imposition of collateral consequences. ${ }^{10}$

Scholars have used these examinations of fairness and the roles of governmental actors in the lives of individual ex-offenders as catalysts for explorations of collateral consequences in the community context in order to reveal the destructive nature of criminal justice policies on community cohesion and self-determination. ${ }^{11}$ This Article takes the novel approach of examining the deleterious effects of criminal justice policies on communities as a "dignity taking" - a taking that "occurs when a state directly or indirectly destroys or confiscates property rights from owners or occupiers and the intentional or unintentional outcome is dehumanization or infantilization." 12

In her seminal work on "dignity takings," Bernadette Atuahene noted that "individuals and communities are deprived of dignity when subject to dehumanization, infantilization, or community destruction;" 13 "community destruction" occurs when "community members are dehumanized or infantilized, involuntarily uprooted, and deprived of the social and emotional ties that define and sustain them." 14 Thus, I argue that the effects of collateral consequences on individual community members collectively amount to a "community dignity taking" - the direct result of "community destruction," as described by Atuahene.

Part II of this Article discusses the genesis of the "dignity taking" analysis (including that of the "community dignity taking") and its development and expansion as a sociolegal concept. It also examines the intersection of criminalization and dignity takings on the individual. Part III explores the relationship between individual "dignity takings" and "community dignity takings."

10. Jefferson-Jones, A Good Name, supra note 7, at 500-01 (citations omitted).

11. See generally CLEAR, supra note 3 .

12. Bernadette Atuahene, Dignity Takings and Dignity Restoration: Creating a New Theoretical Framework for Understanding Involuntary Property Loss and the Remedies Required, 41 L. \& SoC. INQUIRY 796, 817 (2016) [hereinafter Atuahene, Dignity Takings and Dignity Restoration].

13. Id. at 801 (emphasis added).

14. Bernadette Atuahene, Takings as a Sociolegal Concept: An Interdisciplinary Examination of Involuntary Property Loss, 12 ANN. REV. L. \& SoC. SCI. 171, 179 tbl.1 (2016) [hereinafter Atuahene, Takings as a Sociolegal Concept]. 


\section{DIGNITY TAKINGS AND THE INDIVIDUAL}

Bernadette Atuahene originally developed the idea of the "dignity taking" in the context of the apartheid-era taking of land from Black South Africans. ${ }^{15}$ A taking can be classified as a "dignity taking" "when the state confiscates property from groups that have been dehumanized or infantilized."16 Scholars have applied Atuahene's analysis to find dignity takings in varied circumstances involving real and personal property deprivations by state actors, including the theft of Jewish and Gypsy property in France and the Netherlands during World War II, ${ }^{17}$ Israel's dispossession of the Bedouins, ${ }^{18}$ the looting and burning of AfricanAmerican property during and after the Tulsa race riot of $1921,{ }^{19}$ the separation of the Hopi people from their sacred lands, ${ }^{20}$ and the forced evictions of Chinese peasants to make room for rapidly expanding urban centers. ${ }^{21}$

Despite this wave of new scholarship, inquiry into dignity takings is still a developing area of sociolegal inquiry. ${ }^{22}$ As Atuahene recounts, historically, the term "taking" has been used by legal scholars exclusively to mean a "constitutional taking." ${ }^{23}$ A "taking," however, may occur any time "a person, entity, or state confiscates, destroys, or diminishes rights to property without the informed consent of the rights holders." 24

This more expansive view of takings allows for analyses that examine more than just the economic value of the property taken, but rather extend to its emotional, social, political and cultural value. Additionally, this broader definition of the term 'taking' invites a sociolegal approach to these analyses that embraces the methodologies of diverse fields such

15. Bernadette Atuahene, We Want What's Ours: Learning from South AFrica's LAND RESTITUTION PROGRAM (2014) [hereinafter AtuAHENE, We WANT What's OURS].

16. Id.

17. Wouter Veraart, Two Rounds of Postwar Restitution and Dignity Restoration in the Netherlands and France, 41 L. \& Soc. INQUIRY 956, 956-59 (2016).

18. Alexandre (Sandy) Kedar, Dignity Taking and Dispossession in Israel, 41 L. \& Soc. INQUIRY 866, 866-67, 870-82 (2016).

19. Alfred L. Brophy, When More Than Property is Lost: The Dignity Losses and Restoration in the Tulsa Riot of 1921, 41 L. \& SOC. INQUIRY 824, 824, 826-31 (2016).

20. Justin B. Richland, Dignity as (Self-) Determination: Hopi Sovereignty in the Face of US Dispossessions, 41 L. \& Soc. INQUIRY 917, 922-34 (2016).

21. Eva Pils, Resisting Dignity Takings in China, 41 L. \& SOC. INQUIRY 888, 889-94 (2016).

22. See Atuahene, Takings as a Sociolegal Concept, supra note 14, at 191.

23. Id. at 173 (citing Richard A. EPSTEIN, TAKINGS PRIVATE PROPERTY AND the POWER OF EMINENT DOMAIN (1985)).

24. Id. 
as psychology, anthropology, political science, and geography, as well as traditionally-related fields such as law and economics.

Prior to the introduction of the dignity taking, "sociolegal scholars [had] not treated the intersecting deprivation of property and dignity as an area worthy of systematic examination and analysis." 26 "This is particularly true in the context of the taking of intangible property, especially where that taking intersects with the criminal justice system."27 Scholars have just begun to examine both criminal punishment of individuals and community destruction as dignity takings. Their work demonstrates that the dignity taking analysis can also be applied in instances of state-sponsored takings of intangible property, including where those takings intersect with criminal punishment. ${ }^{28}$ The issues of criminal punishment and community destruction, however, have been explored separately. Scholars have not addressed the phenomenon of criminal punishment as a "community dignity taking." This Article extends the dignity taking paradigm into this area.

My previous scholarship has extended the dignity taking analysis to the damage to individuals' reputational "status property" 29 caused by criminal history and ex-offender status. ${ }^{30}$ This Article adds to this new

25. Jefferson-Jones, Extending “Dignity Takings," supra note 8, at 866 (citation omitted); see Atuahene, Takings as a Sociolegal Concept, supra note 14, at 171-74.

26. Atuahene, Dignity Takings and Dignity Restoration, supra note 12, at 797.

27. Jefferson-Jones, Extending “Dignity Takings," supra note 8, at 870 (citation omitted); see Atuahene, Takings as a Sociolegal Concept, supra note 14, at 191 ("[F]urther investigation [of dignity takings] is necessary, especially in the area[] of . . . intangible property ....").

28. See, e.g., Acevedo, Restoring Community Dignity, supra note 1, at 622, 625-31; John Felipe Acevedo, Dignity Takings in the Criminal Law of 17th Century England and the Massachusetts Bay Colony, 92 CHI.-KENT L. REV. 743 (2018) (exploring the question as to when punishment for criminal activity constitutes a dignity taking and arguing that in the Massachusetts Bay Colony, criminal punishment amounted to a dignity taking due to the degradation of bodies and confiscation of property); Andrew S. Baer, Dignity Restoration and the Chicago Police Torture Reparations Ordinance, 92 CHI.-KENT L. REV. 769 (2018) (examining a police torture scandal through the lens of dignity takings and then discussing the role of dignity restoration of those affected by police violence though participation in social movement organizations); Jefferson-Jones, Extending "Dignity Takings," supra note 8, at 158; Lua Kamal Yuille, Dignity Takings in Gangland's Suburban Frontier, 92 ChI.-Kent L. REv. 793 (2018) (studying Monrovia, California's gang injunction through the dignity taking framework and illustrating how these injunctions harm identity and community feelings to deprive the enjoined individuals of dignity in a way that constitutes a dignity taking).

29. "Status property" is property that is linked to identity. Jefferson-Jones, A Good Name, supra note 7, at 510-12; see also Cheryl I. Harris, Whiteness as Property, 106 HARV. L. REV. 1709, 1714 (1993) (noting that "whiteness"-_egal recognition as being racially "white"-is a form of status property).

30. See generally Jefferson-Jones, Extending “Dignity Takings," supra note 8, at 865 (arguing that: "(1) through the continued attachment of stigma as ex-offender status and the myriad collateral consequences attendant to that status, the state both directly and indirectly destroys the reputation-a form of 'status property' - of the previously convicted; and (2) the intentional or unintentional 
sociolegal field by further extending the dignity takings analysis to the communities from which many with ex-offender status come, to which they return, and in which their families reside.

A brief examination of the scope of incarceration and of the imposition of collateral consequences in the United States bears out the truth of the contention that, "[t]he continued reputational damage, stigmatization, and collateral consequences suffered by the previously-convicted rises to the level of a dignity taking because these individuals are dehumanized and infantilized." 31

\section{A. Dehumanization}

\section{The War on Drugs and Dehumanization}

The United States has the highest incarceration rate in the world, incarcerating 693 people for every 100,000 residents as of $2016 .^{32}$ The effects of a criminal conviction and incarceration do not end upon one's having served his or her sentence. Rather, due to the attachment of collateral consequences, the end of an individual's judge-imposed sentence is often just the beginning of his or her lifelong contact with the criminal justice system.

Collateral consequences are numerous and vary from state to state. The Criminal Justice Section of the American Bar Association and the

outcome is dehumanization or infantilization. Thus, a 'dignity taking' has occurred.”).

In previous work I have also explored the collateral consequences of incarceration and the reputational damage caused by criminal history as a constitutional taking. See generally Jefferson-Jones, A Good Name, supra note 7 (establishing the reputations of previously convicted persons as "status property" which can be taken through government regulation and, thus, is compensable; reasoning that the stigma of a criminal record functions as a collateral consequence of conviction that attaches to "offender status;" describing the negative effects of stigma attachment that are suffered by those with criminal records; applying a regulatory takings analysis to the reputational damage suffered by the previously convicted and articulating the idea of affording a "rebiography right" to the previously convicted; and examining the limits of process in actually affording a rebiography right to reentering individuals and weighing formal process (through courts and administrative agencies, for example) against non-process (i.e., policies that prevent inquiries regarding an individual's criminal history)); Jamila Jefferson-Jones, A Second Chance: Rebiography as “Just Compensation,” 117 W. VA. L. REV. 203, 204-30 (2014) [hereinafter Jefferson-Jones, A Second Chance] (demonstrating "that "just compensation' is owed to the previously convicted and that the way to provide it is through establishing a 'rebiography right,' stemming from the taking of a constitutionally cognizable property right;" applying the regulatory takings analysis used in A Good Name to actual cases and using statistics on the employment prospects and recidivism rates of previously convicted persons to argue that rebiography is necessary; and examining legislative and judicial options for rebiography).

31. Jefferson-Jones, Extending “Dignity Takings, ” supra note 8, at 879.

32. Press Release, Peter Wagner \& Allison Walsh, Prison Pol'y Initiative, States of Incarceration: The Global Context 2016 (June 16, 2016), https://www.prisonpolicy.org/global/ 2016.html. 
National Institute of Justice have compiled all of the codified collateral consequences across the United States into the National Inventory of the Collateral Consequences of Conviction (NICCC). ${ }^{33}$ As of May 2018, there were 48,229 collateral consequences catalogued in the NICCC. ${ }^{34}$ The NICCC groups collateral consequence laws into fourteen categories: (1) business license and other property rights; (2) education; (3) employment; (4) family/domestic rights; (5) government benefits; (6) government contracting and program participation; (7) government loans and grants; (8) housing; (9) judicial rights; (10) motor vehicle licensure; (11) occupational and professional license and certification; (12) political and civic participation; (13) recreational license, including firearms; and (14) registration, notification, and residency restrictions. ${ }^{35}$ The collateral consequences in each of these fourteen categories result in either the dehumanization of those with ex-offender status, infantilization of this group of individuals, or both.

Atuahene defines dehumanization as "the failure to recognize an individual's or group's humanity." 36 Jalila Jefferson-Bullock has noted that those with criminal histories suffer from both social and moral dignity degradation resulting in dehumanization:

Criminal punishment, particularly incarceration, is socially and morally degrading because it incontrovertibly extirpates offenders' social standing and overall acceptance as equally human. As a result of imprisonment, prisoners suffer both social and moral indignation. ${ }^{37}$

John Acevedo has outlined the history of the dehumanization of those with criminal records in the United States. He posits that it began with the War on Drugs:

The dehumanization of people with criminal records arguably started in the 1970s, when the effects of the "War on Drugs" began to be really felt and the militarization of the police (including the development of SWAT teams) took off. President Nixon may have invented the criminal as

33. National Inventory of the Collateral Consequences of Conviction Home Page, COUNCIL STATE GOV’TS JUST. CTR., https://niccc.csgjusticecenter.org/ (last visited May 8, 2018).

34. National Inventory of the Collateral Consequences of Conviction Search, COUNCIL STATE GOV'TS JUST. CTR. [hereinafter NICCC Search Page], https://niccc.csgjusticecenter.org/search/ (last visited May 8, 2018).

35. Joshua Kaiser, Essay, Revealing the Hidden Sentence: How to Add Transparency, Legitimacy and Purpose to "Collateral” Punishment Policy, 10 HARV. L. \& POL'Y REV. 123, 132-33 tbl.1 (2016); see also NICCC Search Page, supra note 34.

36. Atuahene, Dignity Takings and Dignity Restoration, supra note 12, at 801.

37. Jalila Jefferson-Bullock, Quelling the Silver Tsunami: Compassionate Release of Elderly Offenders, 79 OHIO ST. L. J. (forthcoming Fall 2018). 
cultural villain, but President Reagan certainly perfected the image with his rhetoric against . . criminal "predators." That rhetoric paid off in 1986 with the passage of the Anti-Drug Abuse Act, which created mandatory minimum sentences for cocaine distribution and even harsher sentences for crack-cocaine. ${ }^{38}$

These policies were reinforced by and reflected in the news and entertainment media. According to Acevedo, this resulted in "Americans [beginning to] view criminals as wholly without redeeming qualities ... [and with the rise of] [c]riminal-catching ... [as] a sport on shows like Cops ... [to view] criminals ... [as] objects to be hunted" like animals. ${ }^{39}$

In addition to the dehumanization of those with criminal records through the rhetoric of the War on Drugs, dehumanization also "occurs with the imposition of those collateral consequences that deprive persons with ex-offender status of basic necessities such as shelter and the means to procure it (i.e., lawful employment)." ${ }^{\prime 4}$ Together, housing-related and employment-related restrictions make up eighty three percent of the restrictions listed in the NICCC. ${ }^{41}$

Housing-related restrictions account for $8.1 \%$ of the 48,229 collateral consequences in the NICCC. ${ }^{42}$ These restrictions include such measures as discretionary denial of public housing benefits to those with misdemeanor and/or felony convictions, ${ }^{43}$ as well as ineligibility for protection from discriminatory housing practices. ${ }^{44}$ Despite their relatively small percentage of the total 48,299 collateral consequences, housing restriction can have an outsized impact on an individual's ability to reenter society after a period of incarceration. For instance, the inability to secure housing can negatively affect employment outcomes, which in turn, contributes to high rates of recidivism.

\footnotetext{
38. Acevedo, Restoring Community Dignity, supra note 1, at 630 (citations omitted).

39. Id. at 631 (citations omitted).

40. Jefferson-Jones, Extending “Dignity Takings," supra note 8, at 879.

41. NICCC Search Page, supra note 34. I have combined "employment" as well as "business licenses and other property rights," "government contracting and program participation" and "occupational and professional license and certification" into one "employment-related" category, which accounts for $74.9 \%$ of collateral consequences. Likewise, "housing-related," which accounts for $8.1 \%$ of collateral consequences, includes "housing" as well as "registration, notification, and residency restrictions."

42. Id. This $8.1 \%$ includes registration, notification, and residency restrictions $(7.5 \%)$. The statistic of $8.1 \%$ accounts for overlap and double-counting.

43. See, e.g., LA. STAT. ANN. § 40:501 (West 2012) (giving housing authorities ability to find those who have exhibited criminal behavior unsuitable for occupancy).

44. See, e.g., Kan. Admin. Regs. § 21-60-15 (2018) (applying to those with controlled substance convictions).
} 
Employment-related restrictions represent $74.9 \%$ of the 48,229 restrictions listed in the NICCC. ${ }^{45}$ Thus, employment-related restrictions account for the majority of the collateral consequences imposed on those with ex-offender status. These restrictions include both discretionary ${ }^{46}$ and automatic ${ }^{47}$ denials of professional licenses. As noted above, employment is critical to successful reentry.

Besides the practical, positive effects of housing and employment on combating recidivism, there is also their effect on perceptions of human worth. "[T]here is an explicit and recognized connection between housing and dignity." 48 As one scholar has noted, "[h] $[\mathrm{h}$ ousing is much more than shelter and a place to live; it is a symbol of personal worth and identity." 49 Moreover, internationally, this connection is acknowledged in the Universal Declaration of Human Rights, ${ }^{50}$ the International Covenant on Economic, Social and Cultural Rights, ${ }^{51}$ and the International Covenant on Political Rights. ${ }^{52}$

Like housing, work is also:

intrinsically dignity-affirming. ... [and] increasing recognition has been given to the psychological importance of not just work itself, but of dignity in the work environment. Thus, given the place that work holds in the psyche and in society, denials of the ability to work, and to avail

45. NICCC Search Page, supra note 34. This $74.9 \%$ includes business license restrictions $(32.9 \%)$ and occupational and professional license certification restriction $(34.8 \%)$. The statistic of $74.9 \%$ accounts for overlap and double-counting.

46. See, e.g., AlA. Admin CODE r. 540-X-3-.05 (Westlaw, Westlaw through the Jan. 31, 2018 Administrative Monthly) (denying limited certificate of qualification to practice medicine to both those with felony and/or misdemeanor convictions).

47. See, e.g., 24 DEL. CODE $§ 1808$ (2014) (instructing applicants for plumbing licenses with felony convictions to apply for a waiver with The State Board of Plumbing, Heating, Air Conditioning, Ventilation and Refrigeration Examiners).

48. Jefferson-Jones, Extending “Dignity Takings," supra note 8, at 883.

49. Kevin Fox Gotham, Race, Real Estate, and Uneven Development: The Kansas CiTY EXPERIENCE, 1900-2010 7 (2nd ed., 2014).

50. Universal Declaration of Human Rights, G.A. Res. 217 (III) A, art. 25(1) (Dec. 10, 1948) ("Everyone has the right to a standard of living adequate for the health and well-being of himself and his family, including ... housing ....”).

51. International Covenant on Economic, Social and Cultural Rights, G.A. Res. 2200A (XXI), art. 11(1) (Dec. 16, 1966) ("The States Parties to the present Covenant recognize the right of everyone to an adequate standard of living for himself and his family, including adequate ... housing and to the continuous improvement of living conditions.").

52. International Covenant on Civil and Political Rights, G.A. Res. 2200A (XXI), art. 12(1) (Dec. 16, 1966) ("Everyone lawfully within the territory of a State shall, within that territory, have the right to ... freedom to choose his residence."). 
oneself of the benefits of work, are examples of the dehumanization of those with criminal histories. ${ }^{53}$

\section{Race, Crime, and Dehumanization}

The dehumanization of those with criminal records cannot be decoupled from notions of white racial superiority and non-whiteparticularly Black ${ }^{54}$-inferiority. Acevedo notes that, not only do "Americans view criminals as wholly without redeeming qualities," but that they also "view minorities as criminally inclined." 55 In her seminal book, The New Jim Crow, Michelle Alexander argued that the American criminal justice system has "redesigned" the racial caste system, but has, ultimately, preserved it:

Once you are labeled a felon, the old forms of discrimination [against African-Americans] - employment discrimination, housing discrimination, denial of the right to vote, denial of educational opportunity, denial of food stamps and other public benefits, and exclusion from jury service - are suddenly legal. As a criminal, you have scarcely more rights, and arguably less respect, than a black man living in Alabama at the height of Jim Crow. ${ }^{56}$

Thus, given that the deprivations enacted through the imposition of collateral consequences mirror those imposed upon African-Americans during the Jim Crow Era, it can be argued that even those collateral consequences that are infantilizing in nature can also have dehumanizing effects when viewed through the lens of racial subordination.

53. Jefferson-Jones, Extending "Dignity Takings," supra note 8, at 883.

54. There is some dispute as to the capitalization of "Black" and "white." Compare Kimberlé Williams Crenshaw, Mapping the Margins: Intersectionality, Identity Politics and Violence Against Women of Color, 43 STAN. L. REV. 1241, 1244 n.6 (1991) (capitalizing "Black" when referring to people of African descent individually or collectively because "Blacks, like Asians, Latinos, and other 'minorities,' constitute a specific cultural group and, as such, require denotation as a proper noun;" arguing that one should not capitalize "white," "which is not a proper noun, since whites do not constitute a specific cultural group") with Brant T. Lee, Critical Race Theory: History, Evolution, and New Frontiers: The Network Economic Effects of Whiteness, 53 AM. U. L. REV. 1259, 1260 n.1 (2004) ('I capitalize 'White' and 'Whiteness' throughout, on the premise that these terms are not natural, objective descriptions of a biological characteristic but instead represent a socially and culturally constructed identity category, much like religious or national affiliations, and therefore should be capitalized."). Given the use of Black in the context of this Article, I choose to capitalize the term "Black" when referring to people of African descent individually and/or collectively.

55. Acevedo, Restoring Community Dignity, supra note 1, at 631.

56. ALEXANDER, supra note 1 , at 2. 


\section{B. Infantilization}

"Collateral consequences, such as restrictions on the franchise, along with measures such as post-release supervision, work to infantilize those with ex-offender status." ${ }^{\text {" }}$ Atuahene distinguishes between "dehumanization" and "infantilization" as follows:

Infantilization is a dignity deprivation distinct from dehumanization because it is predicated on a lack of autonomy rather than on a lack of human worth. Infantilization is the restriction of an individual's or group's autonomy based on the failure to recognize and respect their full capacity to reason. While the person's humanness may be acknowledged, his or her capacity for rational self-governance is not. Most commonly, infantilization involves treating adults as if they were minors, and thus placing them under the authority of another, robbing them of their autonomy. ${ }^{38}$

Good examples of the lack of autonomy imposed upon those with exoffender status can be found in the collateral consequences that impact political and civic participation. ${ }^{59}$

\section{Infantilization Through Collateral Consequences that Impact Political and Civic Participation}

Of the 48,229 collateral consequences listed in the NICCC database, restrictions on political and civic participation account for $11.7 \% .{ }^{60}$ Those that bar individuals with ex-offender status from voting are the most common. ${ }^{61}$ States, however, also bar those with ex-offender status from serving on juries ${ }^{62}$ or holding elected ${ }^{63}$ or appointed public offices. ${ }^{64}$ "Like minors, these adult members of society are denied the autonomy that comes with participation in the body politic. Instead, other members of

\footnotetext{
57. Jefferson-Jones, Extending “Dignity Takings," supra note 8, at 879.

58. Atuahene, Dignity Takings and Dignity Restoration, supra note 12, at 801.

59. See Jefferson-Jones, Extending “Dignity Takings," supra note 8, at 884.

60. NICCC Search Page, supra note 34.

61. See, e.g., W. VA. Const. art. IV, § 1.

62. See, e.g., ARIZ. R. CIV. P. 47.

63. See, e.g., CAL. GOV'T. CODE $\S 1021$ (West 2010).

64. See, e.g., IDAHO CODE $\S 42-3109$ (West, Westlaw through 2018 Second Reg. Sess.) (having the effect of prohibiting those with felony convictions from serving as flood control district commissioner as board members must be qualified voters, making felons ineligible until voting rights are restored).
} 
society are charged with administering the government and its polities without their input, thus 'placing them under the authority of another."

\section{Post-Release Supervision as Infantilizing}

Post-release supervision, such as probation and parole, also serves to infantilize reentering individuals. On the one hand, incarceration is purposeful infantilization - a curtailing of autonomy as punishment. ${ }^{66} \mathrm{On}$ the other hand, "[p]ost-release supervision is a purposeful extension of this incarcerative infantilization." 67 "The infantilization of the reentering person does not appear to recognize the restorative or rehabilitative purposes of criminal punishment, rather it seems to be rooted in retribution and incapacitation. It, therefore, is arguably both infantilizing in its effect, and dehumanizing in its purpose and raison-d'être." ${ }^{\circ 8}$

The admixture of dehumanization and infantilization through the imposition of collateral consequences, colored by racial subordination, works to negatively affect, not only individuals, but also the communities from which those with ex-offender status come and to which they return. Thus, one of the legacies of mass incarceration resulting from the War on Drugs is a resulting "community dignity taking."

\section{COMMUNITY DESTRUCTION: HOW INDIVIDUAL DIGNITY TAKINGS RESULT IN "COMMUNITY DIGNITY TAKINGS"}

Individual reputational damage can infect whole communities. Thus, where there are large numbers of community members with criminal histories, the community/neighborhood and the community members who do not bear ex-offender status - both individually and collectively — suffer from "courtesy stigma" 69 - a stigma that attaches to those associated with the person who bears the primary stigma. The latest scholarship regarding dignity takings of collective property bears out the existence and the effect of such "courtesy stigma" in the dignity takings context. These dignity takings effecting communities have been applied in the context of the closure of community institutions as varied as gay bathhouses ${ }^{70}$ and

\footnotetext{
65. Jefferson-Jones, Extending “Dignity Takings," supra note 8, at 884 (quoting Atuahene, Dignity Takings and Dignity Restoration, supra note 12, at 801).

66. See id. at 885 .

67. See id.

68. Id. (1963).

69. ERving Goffman, Stigma: Notes on the Management of Spoiled Identity 31

70. See generally Stephen M. Engel \& Timothy S. Lyle, Fucking with Dignity: Public Sex,
} 
schools $^{71}$ and hospitals ${ }^{72}$ in minority neighborhoods. Scholars have also applied these concepts in the context of the destruction of, not just single institutions in minority neighborhoods, but also to the destruction of entire minority communities. ${ }^{73}$ Both the scholars examining the destruction of community institutions and those examining the destruction of entire communities focus primarily on the physical loss or destruction of neighborhoods or community spaces. Yet, it is also necessary to "examine community degradation and destruction in the instance where the community is still there physically, but is nonetheless severely damaged." $" 74$

As Atuahene has described it, a "dignity taking" may include "community destruction" as well as "dehumanization" or "infantilization." " The inclusion of community destruction as a dignity taking element creates a bridge between dignity takings that seemingly solely affect individuals and those that also affect the same individuals' neighborhoods and communities. For instance, in their examination of the closing of gay bathhouses as dignity takings, as Stephen Engel and Timothy Lyle observed the following:

Atuahene moves the concept of takings beyond its traditional connection with property and with private ownership.... The taking assaults the dignity of the individual who is connected with the confiscated property. [Moreover], a taking may affect more than just the owner of the property. ... Individuals who utilize the property as a critical site for self-, cultural-, and community-development can also be affected by the confiscation. ${ }^{76}$

Queer Intimate Kinship, and How the AIDS Epidemic Bathhouse Closures Constituted a Dignity Taking, 92 CHI.-KENT L. REV. 961 (2018) (exploring municipal authorities' closure of gay bathhouses in San Francisco and New York City in 1984 and 1985, respectively as a dignity takings affecting those who "utilize[d] the property as a critical site for self-, cultural-, and community-development.").

71. See generally Matthew Patrick Shaw, Creating the Urban Educational Desert Through School Closures and Dignity Taking, 92 CHI.-KENT L. REV. 1087 (2018) (showing that, in the schoolclosure context, "legal and community-based concepts of school property are at fundamental odds with each other.").

72. See generally Shaun Ossei-Owusu, The State Giveth and Taketh Away: Race, Class, and Urban Hospital Closings, 92 CHI.-KENT L. REV. 1037 (2018) (applying the "dignity takings" analysis to "demonstrate how [urban] hospital closings help enrich and supplement [Atuahene's] . . . concepts by exploring the trajectory of Martin Luther King, Jr. Community Hospital, an institution that serves [majority-minority] South Los Angeles, California").

73. See generally Thomas W. Joo, Urban Renewal and Sacramento's Lost Japantown, 92 CHI.KENT L. REV. 1005 (2018).

74. Jefferson-Jones, Extending “Dignity Takings," supra note 8, at 886.

75. Atuahene, Dignity Takings and Dignity Restoration, supra note 12, at 801 ("Individuals and communities are deprived of dignity when subject to dehumanization, infantilization, or community destruction." (emphasis added)).

76. Engel \& Lyle, supra note 70, at 963. 
Thus, in the case of stigmatization and community destruction in communities with high numbers of incarcerated members or of members with ex-offender status, it is not necessary to show physical confiscations of property belonging to particular individuals. Rather, it is sufficient to demonstrate that the infantilization and dehumanization of those with exoffender status serves to bestow a measure of stigma on those neighborhoods and communities with high numbers of members with criminal histories. This stigma leads to over-policing, underfunding, social and economic isolation and, ultimately, destruction of the very fabric of those communities. Therefore, members of those communities, whether owners, or occupiers, whether bearing ex-offender status or not, suffer a dignity taking.

\section{A. The Intersection of Community Destruction and Racial Disparities in Punishment}

Andrew Baer, examined the torture and killing of Black residents by the Chicago Police Department in the 1970s and 1980s as a dignity taking. ${ }^{77}$ Baer focused, not just on the individual " dignity taking [which] occurs when the police take a person's body through physical abuse or extra-judicial murder," ${ }^{78}$ but also on the effects of such individual dignity takings on the individual's community:

[These individual dignity takings] prevented future earnings through wrongful conviction or over-conviction. In addition, survivors' family members and communities also suffered the loss of an important interpersonal relationship, be it neighbor, co-worker, friend, lover, sibling, son, or other. Beyond the immeasurable loss of intimacy, pleasure, and comfort, the taking of an individual from a community also included the measurable loss of work, income, or other economic contribution needed for collective survival in a de-industrial urban environment. ${ }^{79}$

This is particularly true for poor, majority Black neighborhoods. For instance, the imprisonment rate for Black males is six times that of white males: Black males are imprisoned at a rate of 2,415 per 100,000 residents, while white males are imprisoned at a rate of 400 per 100,000 residents. ${ }^{80}$ The imprisonment rate for Black females is nearly double that of white

\footnotetext{
77. Baer, supra note 28.

78. Id. at 773 (quoting Acevedo, Restoring Community Dignity, supra note 1, at 628-29).

79. Id. (citation omitted).

80. E. Ann Carson, Bureau of Justice Statistics, Prisoners in 2016 13, 15 tbl.1 (2018), https://www.bjs.gov/content/pub/pdf/p16.pdf.
} 
females: Black females are imprisoned at a rate of 96 per 100,000 residents, while white females are imprisoned at a rate of 49 per 100,000 residents. ${ }^{81}$

The racial imprisonment disparity is particularly pronounced among the younger population. At the end of $2016,13 \%$ of imprisoned nonHispanic Black males were ages 18-24, whereas only $7 \%$ of imprisoned non-Hispanic white males were in this age range. ${ }^{82}$ Additionally, Black males ages 18-19 have the highest incarceration disparity, being 11.8 times more likely to be in prison than white males of the same age. ${ }^{83}$ Likewise, Black females ages 18-19 were 3.1 times more likely to be imprisoned than white females of the same age. ${ }^{84}$

\section{B. "Punishment's Place" ${ }^{85}$ : Concentrated Incarceration, Return, and Disadvantage as Community Destruction}

Despite the United States' high incarceration rate for individuals, incarceration is actually "quite rare" in many U.S. communities. ${ }^{86}$ Rather, "a small number of communities bear the disproportionate brunt of U.S. crime policy's experiment with mass incarceration." $" 87$ The communities are both "communities of concentrated return" and "communities of concentrated disadvantage." 88 For members of these communities, incarceration is "a disturbingly common occurrence," resulting in its having become "a normal life event for many disadvantaged young men [who are] more likely to end up in prison than to attend college." ${ }^{\prime 9}$

Unsurprisingly, the population of reentering individuals is also distributed unevenly across the country. ${ }^{90}$ Reentering individuals are concentrated in "core counties" containing "the central city of a metropolitan area." 91 And, "[w]ithin these [core] counties, a small number

\footnotetext{
81. Id.

82. $I d$.

83. Id.

84. Id. at 1 .

85. This turn of phrase is from Sampson \& Loeffler, supra note 5.

86. Sampson \& Loeffler, supra note 5, at 20.

87. Id.; see generally CLEAR, supra note 3 .

88. Jeremy Travis, But They All Come Back: Facing the Challenges of Prisoner REENTRY 282 (2005).

89. Sampson \& Loeffler, supra note 5, at 20.

90. TRAVIS, supra note 88 , at 282 .

91. Id. at 281
} 
of communities bear the burden of reintegrating record numbers of returning prisoners." 92

\section{Community Viability}

In his examination of the closing of a minority-serving urban hospital as a dignity taking, Shaun Ossei-Owusu noted that "Atuahene's description of the term [dignity taking] . . . suggest[s] . . [that] her concept is roomy enough to accommodate . . . resource deprivation." ${ }^{.93}$ Although Ossei-Owusu was referring to the government's deprivation of economic resources to the hospital, ${ }^{94}$ "resource deprivation" in the affected core communities discussed above is certainly one of the outcomes of the War on Drugs and mass incarceration. These resources, however, include not just economic resources, but also collective resources, such as social controls and political participation and power.

\section{Economic Resources}

Those with ex-offender status have difficulties both finding and keeping employment. ${ }^{95}$ They also earn less during their lifetimes than do those without ex-offender status. ${ }^{96}$ Thus, chronic unemployment and underemployment plunges their families into chronic poverty and economic stress. As criminologist Todd Clear put it, in neighborhoods of high incarceration concentration, "[e]very family has a member who has limited labor-market options." 97

\section{Social Controls}

Families are not just negatively affected by the economic losses incurred by the removal of potential wage earners or by the return of

\footnotetext{
92. Id.

93. Ossei-Owusu, supra note 72, at 1054.

94. See generally id. (charting the history of the King/Drew Medical Center in South Los Angeles, including its struggle to remain sufficiently funded to serve its target population of the area's Black and Latino residents).

95. ClEAR, supra note 3, at 9; TRAVIS, supra note 88, at 291 ("'II]ncarceration severs the employment relationship for large numbers of individuals [and] [w] hen prisoners return to their home communities, their prospects of employment are bleak."); see generally DEVAH PAGER, MARKED: RACE, CRIME, AND FINDING WORK IN AN ERA OF MASS INCARCERATION (2007) (reporting the result of the author's empirical study charting the obstacles faced in the employment arena by those with exoffender status).

96. CLEAR, supra note 3, at 9.

97. Id. (emphasis added).
} 
members with dramatically diminished employment options, but they also lose the positive effects of community-based informal social controls. ${ }^{98}$ Such controls consists of "social forces that produce compliance with community norms but are not derived from state power." indispensable in exerting such informal social control and incarceration weakens its role. ${ }^{100}$ Moreover, families with incarcerated members tend to isolate themselves from other members of the community, thus losing the benefit of community social control on their family members. ${ }^{101}$

\section{Collective Political Participation and Power}

The isolation suffered by families touched by the criminal justice system reaches into the realm of political and civic participation. Individuals, their families and, ultimately, their entire communities lose political power due to felon disenfranchisement laws and other collateral consequences that bar civic participation, such as jury service or holding elected or appointed office. ${ }^{102}$ The entire community is, thus, infantilized through this loss of political autonomy.

\section{CONCLUSION}

The impact on communities of the War on Drugs and the resulting mass incarceration is astounding:

Hundreds of thousands of residents each year are, as a result of criminal activity, removed from and returned to their communities with diminished social capital. . . These individual effects are then compounded by the broad negative impact of our incarceration policies on the overall social capital of these communities, specifically the network of families, businesses, churches and social institutions. ${ }^{10}$

Scholars have examined these impacts from myriad angles, yet Atuahene's dignity takings analysis opens new avenues of discourse. As Matthew Shaw explains:

More than an economic asset more easily defined as a property interest, Atuahene shows how social investments, particularly those made by

\footnotetext{
98. TRAVIS, supra note 88, at 296-97.

99. Id. at 297

100. Id. at $297-98$.

101. Id.

102. See id. at 289-90.

103. Id. at 297.
} 
multiple actors across generations, infuse land with dignity, a property interest largely unrecognized by legal systems derived from English common law. ${ }^{104}$

Thus, through Athuahene's new sociolegal tool, the people making up a community can express the profound dignitary loss suffered by the psychic damage to the "land" constituting the locus of their community.

The impact of mass incarceration and collateral consequences on the human worth and autonomy of individuals inevitably touches every corner of these impacted communities. These communities, therefore, suffer from a measure of dehumanization and infantilization equal to that of their members. For this reason, it can be concluded that a "community dignity taking" has occurred.

104. Shaw, supra note 71 , at 1108. 